\title{
Pengaruh Motivasi, Disiplin dan Kepuasan Kerja Terhadap Kinerja Karyawan Pada PT. Angkasa Pura II (Persero) Kantor Cabang Kualanamu
}

\author{
Sandhi Fialy Harahap \\ Satria Tirtayasa
}

Program Studi Magister Manajemen, Universitas Muhammadiyah Sumatera Utara Medan, Indonesia Jl. Denai No. 217, Tegal Sari Mandala II, Medan Denai, Kota Medan, Sumatera Utara 20371

Email : sandhifialy94@gmail.com

\begin{abstract}
Abstrak. Berdasarkan riset awal yang dilakukan tentang kinerja ditemukan adanya permasalahanya sesuai dengan indikator kinerja, antara lain: kuantitas pegawai yang masih dinilai kurang untuk menunjang penyelesaian tugas pekerjaan agar sesuai dengan waktu yang telah ditetapkan, ditemukan redahnya kualitas kerja yang dihasilkan pegawai yaitu ada beberapa pekerjaan yang dihasilkan masih kurang optimal, rendahnya produktitifitas organisasi inovasi yang terhambat, semangat kerja menurun, yang dalam keseluruhan ini akan menghambat kinerja karyawan di perusahaan Angkasa Pura II (persero) kantor cabang kualanamu. Tujuan dari penelitian ini adalah untuk mengetahui pengaruh motivasi,disiplin dan kepuasan kerja terhadap kinerja karyawan di PT. Angkasa Pura II (Persero) Kantor Cabang Kualanamu. Penelitian ini menggunakan metode penelitian asosiatif dengan pendekatan deskriptif kuantitatif. Jenis data yang digunakan pada penelitian ini adalah data primer dan data sekunder. Data primer diperoleh dari hasil pengolahan langsung dari objeknya. Sedangkan data sekunder merupakan data yang peneliti peroleh dari buku-buku dan sumber data lainya yang berhubungan dengan pembahasan penelitian ini. Penelitian yang dilakukan untuk mengetahui pengaruh secara parsial dan simultan antara variabel bebas terhadap variabel terikat. Hasil penelitian ini menunjukkan bahwa secara parsial dapat disimpulkan bahwa motivasi, disiplin, dan kepuasan kerja mempunyai pengaruh positif dan signifikan terhadap kinerja. Dari hasil penelitian ini menunjukan bahwa secara simultan dapat disimpulkan bahwa motivasi,disiplin dan kepuasan kerja secara simultan mempunyai pengaruh signifikan terhadap kinerja.
\end{abstract}

Kata Kunci : Motivasi, Disiplin, Kepuasan Kerja, Kinerja

\begin{abstract}
Based on preliminary research conducted on performance, problems were found in accordance with performance indicators, including: the quantity of employees who are still considered to be inadequate to support the completion of work tasks in accordance with the time has been determined, found that the quality of work produced by employees is low, there are some jobs that are produced are still not optimal, the low productivity of an innovation organization is hampered, morale is decreasing, which in this whole will hamper the performance of employees in the company Angkasa Pura II (Persero) kualanamu branch office. The purpose of this study was to determine the effect of motivation, discipline and job satisfaction on employee performance at PT. Angkasa Pura II (Persero) Kualanamu Branch Office. This research uses associative research methods with quantitative descriptive approaches. The type of data used in this study are primary data and secondary data. Primary data obtained from the processing directly from the object. While secondary data is data that researchers obtain from books and other data sources related to the discussion of this study. Research conducted to determine the effect of partially and simultaneously between the independent variable to the dependent variable. The results of this study indicate that partially it can be concluded that motivation, discipline, and job satisfaction have a positive and significant effect on performance. From the results of this study indicate that it can simultaneously be concluded that motivation, discipline and job satisfaction simultaneously have a significant effect on performance.
\end{abstract}

Keywords : Motivation, Discipline, Job Satisfaction, Performance 


\section{PENDAHULUAN}

Kinerja karyawan sebagai salah satu elemen utama yang dapat ditingkatkan apabila karyawan mengetahui apa yang diharapkan kapan dapat berperan serta dinilai atas hasil kinerjanya didasarkan perialaku. Penilaian kinerja harus dilakukan secara adil tidak memihak dan harus manggambarkan kinerja aktual yang akurat. Persoalnya adalah apakah karyawan mempunyai perilaku kompetitif yang tinggi untuk mencapai prestasi kerja yang lebih baik dan melahirkan perilaku yang tidak cepat puas diri terhadap hasil.

Menurut (Wibowo, 2014) mengemukakan bahwa kinerja adalah tentang melakukakan pekerjaan dan hasil yang di capai dari pekerjaan tersebut. Dibutuhkan peningkatan kinerja di setiap karyawan agar tujuan bisa tercapai dan dapat mempercepat pekerjaan yang sudah di tetapkan. Kinerja karyawan akan terus selalu din perhatikan dan diharapkan peningkatan kerja akan berdampak positif bagi kelangsungan pekerja yang ada di PT. Angkasa Pura II.

Di dalam mewujudkan target yang diinginkan karyawan harus mempunyai motivasi yang tinggi agar keberhasilan dapat diraih. Pada intinya motivasi dijadikan salah satu solusi untuk mencapai tujuan. Motivasi juga bisa menjadi penentu keberhasilan. Organisasi tanpa adanya motivasi, maka tujuan ataupun target tidak akan tercapai.

Hasibuan \& Handayani, (2017) dalam penelitianya menyatakan bahwa motivasi timbul dari adanya rasa kebutuhan terhadap diri sendiri dan dorongan keinginan individu yang diarahkan pada tujuan memperoleh kepuasan. Proses motivasi dimulai dengan pengenalan kebutuhan. Salah satu penyebab kompleksnya proses ini adalah karena setiap karyawan memiliki kebutuhan yang berbeda sehingga motivasi kerja yang dimiliki karyawan juga berbeda. Semakin tinggi motivasi kerja yang dimiliki karyawan akan mempengaruhi kinerja karyawan.

Hanya peranan motivasi saja tidak cukup menjadikan salah satu tujuan organisasi dibutuhkan juga kedisiplinan yang harus di bangun setiap karyawan, dikarenakan permasalahan yang terus muncul tiada habisnya dalam hal kepuasan menjadi sorotan utama. Kurangnya kepuasan kerja karyawan berdampak buruk bagi perusahaan dan pencapaian tujuan akan mendapatkan hasil yang memuaskan. Salah satu faktor yang mempengaruhi kinerja karyawan adalah perilaku kedisiplinan. Thurstone dalam Walgito, (2007), berpandang bahwa perilaku merupakan suatu tingkat efek, baik itu bersifat negatif maupun positif dalam hubunganya dengan obyek-obyek psikologis.

Kedisiplinan merupakan suatu yang membuat orang akan menjadi lebih baik di dalam melaksanakan pekerjaan. Kedisiplinan seseoarang dapat muncul ketika seorang karyawan dapat menghargain peraturan. Tujuan dari disiplin ini sendiri adalah untuk dapat memelihara dirinya terhadap peraturan-peraturan perusahaan dan dapat mempengaruhi kinerja karyawan. Kedisiplinan juga membuat karyawan jauh lebih percaya diri dan merubah kinerja karyawan lebih meningkat, akan tetapi apabila kedisiplinan seseorang karyawan kurang maka secara otomatis kinerja karyawan pun ikut menurun, dan kedisiplinan juga kerap sekali diabaikan seseorang karyawan. Pada dasarnya kedisiplinan terhadap karyawan adalah salah satu faktor yang membuat perubahan baik sendiri ataupun halayak banyak. Dan diharapkan kepada pegawai Angkasa Pura II dapat memahami bahwa kedisiplinan bertujuan untuk perubahan yang lebih baik.

Berdasarkan hasil survei awal terkait kinerja Penulis menemukanya adanya permasalahanya sesuai dengan indikator kinerja, antara lain: kuantitas pegawai yang masih dinilai kurang untuk menunjang penyelesaian tugas pekerjaan agar sesuai dengan waktu yang telah ditetapkan, ditemukan redahnya kualitas kerja yang dihasilkan pegawai yaitu ada beberapa pekerjaan yang dihasilkan masih kurang optimal, rendahnya produktitifitas organisasi inovasi yang terhambat, semangat kerja menurun, yang dalam keseluruhan ini akan 
menghambat kinerja karyawan di perusahaan Angkasa Pura II (persero) kantor cabang kualanamu.

Berdasarkan survei awal tentang motivasi ditemukan terdapat kecenderungan ditandai dengan loyalitas karyawan menurun. Bila seseoang termotivasi maka ia akan berupaya sekuat tenaga untuk mencapai tujuan. Pada umumnya kinerja yang tinggi dihubungkan dengan motivasi yang tinggi. Sebaliknya, motivasi yang rendah dihubungkan dengan kinerja yang rendah. Sedangkan survei awal tentang disiplin ditemukan beberapa karyawan yang tidak dapat menyelesaikan pekerjaanya secara efisien, dan terdapat juga beberapa karyawan yang kurang efektif memanfaatkan waktu di dalam pekerjaan. Dan diharapkan kepada karyawan dapat mengerjakan pekerjaanya secara efisien dan dapat memanfaatkan waktu dalam berkerja.

Berdasarkan survei awal tentang kepuasan kerja terdapat beberapa karyawan yang merasa kepuasan kerjanya menurun yaitu perasaan didalam menyelesaikan pekerjaan yang tidak dapat diukur kepuasanya, dan perasaan dalam penilaian karyawan yang kurang terlaksana dengan baik. Salah satu faktor pendukung keberhasilan PT. Angkasa Pura II yaitu kepuasan kerja. Hal ini tidak kalah penting dari tiga poin di atas karena dengan terciptanya kepuasan kerja maka pekerjaan seseorang karyawan dapat terselesaikan dengan baik. Akan tetapi fenomena yang sering kita hadapin masih banyak karyawan kurang dengan kepuasan kerjanya, sehingga dapat membuat lambat proses pekerjaanya. Kepuasan kerja akan tercipta apabila semua peran di atas bersinegri karena motivasi dapat memicu semangat seorang karyawan ataupun kedisiplinan diterapkan untuk perubahan baik sendiri dan halayak banyak.

\section{LANDASAN TEORI \\ Kinerja}

Kinerja merupakan perilaku nyata yang ditampilkan setiap orang sebagai prestasi kerja yang dihasilkan oleh pegawai sesuai perannya dalam instansi. Menurut Prawirosentono dalam (Edison, Anwar, \& Komariah, 2016), kinerja adalah hasil kerja yang dapat dicapai oleh seseorang atau sekelompok orang dalam suatu organisasi, sesuai dengan wewenang dan tanggung jawab masing-masing, dalam rangka upaya mencapai tujuan organiasi bersangkutan secara legal, tidak melanggar hukum dan sesuai dengan norma dan etika.

Menurut (Hasibuan, 2016), kinerja adalah suatu hasil kerja yang dicapai seseorang dalam melaksanakan tugas-tugas yang dibebankan kepadanya. Menurut (Moeheriono, 2014) kinerja adalah gambaran mengenai tingkat pencapaian pelaksanaan atau program kegiatan atau kebijakan dalam mewujudkan sasaran, tujuan, visi dan misi organisasi yang dituangkan melalui perencanaan strategis suatu organasi. Menurut Stolovitch dan Keeps dalam (Edison et al., 2016) kinerja adalah seperangkat hasil yang dicapai dan merujuk pada tindakan pencapaian serta pelaksanaan sesuatu pekerjaan yang diminta.

Menurut (Sutrisno, 2016) menyatakan bahwa kinerja merupakan hasil upaya seseorang yang ditemukan oleh kemampuan karakteristik pribadinya serta persepsi terhadap perananya dalam pekerjaan itu. Dari pendapat para ahli diatas, dapat kita simpulkan kinerja adalah suatu hasil kerja yang dapat ditemukan secara kualitas maupun kuantitas dalam melaksanakan tugas yang dibebankan kepada seseorang karyawan yang mewujudkan sasaran, visi, misi, dan tujuan suatu organisasi atau perusahaan. Menurut Pendapat (Simajuntak, 2011), kinerja di pengaruhi 3 faktor yaitu :

1. Faktor Individu, adalah kemampuan dan keterampilan melakukan kerja. Kompetensi seseorang dipengaruhi ole beberapa faktor yang dapat dikelompokan dalam dua golongan yaitu kemampuan dan keterampilan kerja serta motivasi dan etos kerja.

2. Faktor dukungan organisasi, dalam melaksanakan tugasnya, pegawai memerlukan dukungan organisasi tempat iya bekerja. Dukungan tersebut adalah dalam bentuk 
pengorganisasian, penyediaan sarana dan prasarana kerja, kenyamana lingkungan kerja, pengorganisasian yang dimaksud untuk memberi kejelasan bagi setiap orang tentang sasaran yang harus dicapai dan apa yang harus dilakukan untuk mencapai sasaran tersebut. Setiap orang perlu memiliki dan memahami uraian jabatan dan tugas yang jelas.

3. Faktor dukungan manajemen, kinerja perusahaan dan kinerja setiap orang juga sangat tergantung pada kemampuan manajerial para manajemen atau pemimpin, baik dengan membangun sistem kerja dan hubungan industrial yang aman dan harmonis, maupun dengan mengembangkan kompetensi pekerja, demikian juga dengan menumbuhkan motivasi seluruh untuk bekerja secara optimal.

Menurut (Edison et al., 2016), faktor-faktor yang mempengaruhi kinerja antara lain: Kompetensi, Tekonologi/Mesin dan Metode. Menurut (Bernardin \& Russel, 2010) ada beberapa indikator kinerja karyawan sebagai berikut:

1. Kualitas: tingkat dimana hasil aktifitas yang dilakukan mendekati sempurna dalam arti menyesuaikan beberapa cara ideal dari penampilan aktifitas maupun memenuhi tujuan yang diharapkan dari suatu aktifitas.

2. Kuantitas: jumlah yang dihasilkan dalam istilah jumlah unit, jumlah siklus aktifitas yang diselesaikan.

3. Ketepatan waktu: tingkat suatu aktifitas diselesaikan pada waktu awal yang diinginkan, dilihat dari sudut koordinasi dengan hasil output serta memaksimalkan waktu yang tersedia untuk aktifitas lain.

4. Efektifitas: tingkat penggunaan sumber daya manusia, organisasi dimaksimalkan dengan maksud menaikan keuntungan atau mengurangi kerugian dari setiap unit dalam penggunaan sumber daya.

5. Komitmen Organisasi: tingkat dimana pegawai mempunyai komitmen kerja dengan organisasi dan tanggung jawab pegawai terhadap organisasi.

Menurut (Sutrisno, 2016) bahwa terdapat enam indikator kinerja karyawan yaitu:

1. Hasil kerja, yaitu meliputi tingkat kuantitas maupun kualitas yang telah dihasilkan dan sejauhmana pengawasan.

2. Pengetahuan pekerjaan, yaitu pengetahuan yang terkait dengan tugas pekerjaan yang akan berpengaruh langsung terhadap kuantitas dari hasil kerja.

3. Inisiatif, yaitu tingkat inisiatif selama melaksanakan tugas pekerjaan khusunya dalam hal penagangan masalah-masalah yang timbul.

4. Sikap yaitu semangat kerja serta sikap positif dalam melaksanakan tugas pekerjaan.

5. Disiplin waktu dan absensi yaitu ketepatan waktu dan tingkat kehadiran.

\section{Motivasi}

Menurut Gray dalam (Winardi, 2012), mengartikan sebagai motivasi sebagai hasil jumlah proses yang bersifat internal atau eksternal bagi seorang individu, yang menyebabkan timbulnya sikap antusiasme dalam hal melaksanakan kegiatan-kegiatan tertentu. Adapun menurut (Sutrisno, 2016), menyatakan bahwa motivasi adalah suatu faktor yang mendorong seseorang untuk melakukan suatu aktivitas tertentu, oleh karena itu motivasi sering kali diartikan sebagai faktor pendorong perilaku seseorang. Menurut (Rivai \& Sagala, 2013) motivasi adalah serangakain sikap dan nilai-nilai yang mempengaruhi individu untuk mencapai hal yang spesifik sesuai dengan tujuan individu sikap dan nilai tersebut merupakan suatu yang invisible yang memberikan kekuatan untuk mendorong individu bertingkah laku dalam mencapai tujuan. Menurut Ivanko dalam (Hamali, 2016), mendefenisikan motivasi sebagai keinginan dan energi seseorang yang diarahkan untuk pencapain suatu tujuan. Menurut Kondalkar dalam (Hamali, 2016), mengartikan motivasi sebagai salah satu dalam yang 
membakat yang disebabkan oleh kebutuhan, keinginan, dan kemauan yang mendorong seseorang individu untuk menggunakan energy fisik dan mentalnya demi tercapainya tujuan-tujuan yang dinginkan.

Menurut pendapat para ahli diatas, dapat disimpulkan motivasi adalah pemberiaan atau penimbulan motif yang merangsang keinginan dan daya penggerak kemauan bekerja seseorang mengarahkan dan menyalurkan, sikap dan pencapaian tujuan suatu perusahaan.

Motivasi sebagai proses batin atau proses psikologis dalam diri seseorang. Faktor-faktor yang mempengaruhi motivasi terdiri dari beberapa macam. Motivasi yang ada dalam diri seseorang bukan merupakan indikator yang berdiri sendiri. Motivasi itu sendiri muncul sebagai dari interaksi yang terjadi di dalam individu.

Sutrisno, (2016) mengatakan faktor-faktor yang mempengaruhi motivasi ada dua yaitu:

1. Faktor Intern

Faktor intern yang dapat mempengaruhi pemberian motivasi pada seseorang antara lain keinginan untuk dapat hidup, keinginan untuk dapat memiliki keinginan untuk memperoleh pengakuan keinginan untuk berkuasa.

2. Faktor Ekstern

Faktor ekstern juga tidak kalah peranya dalam melemahkan motivasi kerja seseorang, faktor-faktor eksternal itu adalah kondisi lingkungan kerja, kompensasi yang memadai, supervisi, yang baik, adanya jaminan pekerjaan, status dan bertanggung jawab peraturan yang fleksibel.

Motivasi merupakan dorongan untuk bertindak terhadap serangkaian proses perilaku manusia dengan mempertimbangkan arah, intensitas, dan ketekunan pada pencapaian tujuan. Adapun elemen yang terkandung dalam motivasi meliputi unsur membangkitkan, mengarahkan, menjaga, bersifat terus-menerus dan adanya tujuan (Wibowo, 2014). (Sutrisno, 2016), mengatakan bahwa motivasi memiliki komponen, yakni kompenen dalam dan luar. Komponen dalam ialah perubahan dalam diri seseorang, keadaan merasa tidak puas, ketegangan psikologis. Komponen luar ialah apa yang di inginkan seseorang, tujuan yang menjadi arah tingkah lakunya. Jadi, komponen dalam adalah kebutuhan - kebutuhan yang ingin di puaskan, sedangkan komponen luar adalah tujuan yang hendak di capai. Menurut (Sunyoto, 2012) faktor-faktor yang mempengaruhi motivasi ada yaitu: promosi, prestasi kerja, pekerjaan itu sendiri, penghargaan, tanggung jawab, pengakuan dan keberhasilan dalam bekerja. Motivasi adalah suatu faktor yang mendorong seseorang untuk melakukan suatu aktifitas tertentu. Adapun indikator motivasi kerja menurut (Mangkunegara, 2018) meliputi yaitu: kerja keras, orientasi masa depan, tingkat cita-cita yang tinggi, orientasi tugas / sasaran, usaha untuk maju, ketekunan, rekan kerja yang di pilih dan pemanfaatan waktu.

\section{Disiplin}

Disiplin kerja merupakan suatu sikap pegawai yang mencerminkan hormat dan patuh terhadap peraturan maupun ketetapan dari organisasi atau perusahaan, yang ada dalam diri seorang pegawai, yang menyebabkan pegawai tersebut dapat menyesuaikan diri secara sukarela pada peraturan dan ketetapan dari organisasi atau perusahaan (Hamali, 2016). Disiplin kerja adalah suatu sikap kesadaran dan kesediaan dari diri pegawai dalam menaati semua peraturan dan norma-norma yang berlaku di dalam suatu perusahaan (Hasibuan, 2013). Disiplin kerja juga diartikan sebagai suatu tingkat kepatuhan maupun ketaatan terhadap aturan yang berlaku dan siap menerima konsekuensi apabila melanggar peraturan-peraturan.(Fahmi, 2017, hal 75). Dari pernyataan-pernyataan tersebut dapat disimpulkan bahwa disiplin kerja adalah suatu sikap dan perilaku yang dilakukan pegawai dengan melaksanakan, menghargai dan menaati 
peraturan-peraturan yang telah ditetapkan di dalam sutau organisasi atau perusahaan. Berdasarkan disiplin kerja pegawai, ada faktor-faktor yang memperngaruhi disiplin kerja pegawai, yaitu (Hamali, 2016): 1) besar kecilnya pemberian kompensasi, 2) ada tidaknya keteladanan pemimpin dalam perusahaan, 3) ada tidaknya aturan pasti yang dapat dijadikan pegangan, 4) keberanian pimpinan dalam mengambil tindakan, 5) ada tidaknya pengawasan pimpinan, 6) ada tidaknya perhatian kepada para pegawai, 7) diciptakan kebiasaan-kebiasaan yang mendukung tegaknya disiplin. Adapun indikator disiplin kerja pegawai, yaitu (Afandi, 2016): 1) masuk kerja tepat waktu, 2) penggunaan waktu secara efektif, 3) tidak pernah mangkir/tidak kerja, 4) Mematuhi semua perturan organisasi atau perusahaan.

\section{Kepuasan Kerja}

Umar (2011), menyatakan bahwa kepuasan kerja adalah perasaan dan penilaian seseorang atas pekerjaanya, khususnya mengenai kondisi kerjanya, dalam hubunganya dengan apakah pekerjaannya mampu memenuhi harapan, kebutuhan,dan keinginanya. Dari definisi-definisi diatas, dapat disimpulkan bahwa kepuasan kerja adalah keadaan psikis yang menyenangkan yang dirasakan oleh pekerja dalam suatu lingkungan pekerjaan karena terpenuhinya kebutuhan secara memadai. Menurut Hasibuan, (2011) mendifinisikan bahwa kepuasan kerja adalah sikap emosional yang menyenangkan dan mencintai pekerjaannya. Sikap ini dicerminkan oleh moral kerja. Sunyoto, (2012) mendifinisikan bahwa : Kepuasan kerja merupakan sifat individual seseorang sehingga memiliki tingkat kepuasan yang berbeda sesuai dengan sistem nilai-nilai yang berlaku pada dirinya. Hal ini disebabkan oleh adanya perbedaan pada masing-masing individu.Semakin banyak aspek-aspek dalam pekerjaan sesuai dengan keinginan individu tersebut maka semakin tinggi tingkat kepuasan yang dirasakan begitu pula sebaliknya.

Kepuasan kerja adalah keadaan emosional yang menyenangkan atau tidak meyenangkan dimana para karyawan memandang pekerjaan mereka dan beberapa indikator dari kepuasan kerja. Menurut (Hasibuan, 2014) menyatakan bahwa indikator kepuasan kerja yaitu 1) menyenangi pekerjaanya, yaitu seseorang menyenangi pekerjaanya karena ia bisa mengerjakanya, 2) mencintai pekerjaanya, 3) moral kerja, yaitu kesepakatan batinlah yang muncul dari dalam diri seseorang atau sekolompok orang untuk mencapai tujuan tertentu sesuai dengan mutu yang di tetapkan, 4) kedisiplinan, yaitu kondisi yang tercipta dan terbentuk melalui proses dari serangkaian perilaku yang menunjukan nilai-nilai ketaatan, kepatuhan, kesetiaan, keteraturan dan ketertiban, dan 5) prestasi kerja, yaitu hasil kerja yang dicapai seseorang dalam melaksanakan tugas-tugas yang dibebankan kepadanya yang didasarkan atas kecakapan dan kesunguhan serta waktu.

Widodo, (2015) menyatakan bahwa ada beberapa indikator dari kepuasan kerja,yaitu: 1) gaji, yaitu jumlah bayaran yang diterima seseorang akibat dari pelaksanaan keja apakah sesuai dengan kebutuhan dan dirasakan adil, 2) pekerjaan itu sendiri, yaitu isi pekerjaan yang dilakukan seseorang apakah memiliki elemen yang memuaskan, 3) rekan kerja, yaitu teman-teman kepada siapa seseorang senantiasa berinteraksi dalam pelaksanaan pekerjaan. Seseorang dapat merasakan rekan kerjanya sangat menyenagkan atau tidak menyenangkan, 4) atasan, yaitu seseorang senantiasa memberi perintah atau petunjuk dalam pelaksanaan kerja. Cara-cara kerja atasan dapat tidak menyenangkan bagi seseorang atau menyenangkan dan hal ini dapat mempengaruhi kepuasan kerja, 5) promosi, yaitu kemungkinan seseorang dapat berkembang melalui kenaikan jabatan, seseorang dapat merasakan adanyakemungkinan besar untuk naik jabatan atau tidak. Ini juga dapat mempengaruhi tingkat kepuasan kerja seseorang, dan 6) lingkungan kerja yang, yaitu lingkungan fisik dan psikologis. 
Kepuasan kerja mencerminkan sikap seseorang terhadap pekerjaannya. Ini terlihat dalam sikap positif pegawai terhadap pekerjaan dan segala sesuatu yang dihadapi dilingknugan kerjanya. Departemen personalia atau pihak management harus senantiasa memonitor kepuasan kerja, karena hal ini dapat mempengaruhi tingkat absensi, perputaran tenaga kerja, semangat kerja, keluhan-keluhan dan masalah personalia vital lainnya. Menurut (Mathis \& Jackson, 2011) kepuasan kerja adalah keadaan emosi yang positif dan mengealuasipengalaman kerja seseorang. Ketidakpuasan kerja muncul saat harapam-harapan ini tidak terpenuhi. Kepuasan kerja mempunyai banyak dimensi, secara umum adalah kepuasan dalam pekerjaan itu sendiri, gaji, pengakuan, hubungan antara supervisor dengan tenaga kerja, dan kesempatan untuk maju.

\section{METODE PENELITIAN}

Dalam penelitian ini, metode penelitian yang dilakukan adalah dengan metode penelitian asosiatif, menurut (Juliandi, Irfan, \& Manurung, 2015) merupakan penelitian yang bertujuan untuk mengetahui hubungan antara dua variabel atau lebih. Dengan penelitian ini maka akan dapat dibangun suatu teori yang dapat berfungsi untuk menjelaskan, meramalkan dan mengontrol suatu gejala. Dalam penelitian ini akan mengumpulkan data sampel penelitian, sampel penelitian ini dikumpulkan melalui pengisian angket. Sehingga dalam penelitian ini diharapkan dapat mengetahui pengaruh motivasi, disiplin, kepuasan kerja terhadap kinerja karyawan di PT Angkasa Pura II Persero Cabang Kulanamu. Populasi penelitian ini adalah seluruh karyawan di PT. Angkasa Pura II Persero Kantor Cabang Kualanamu berjumlah 35 orang. Dinamakan penelitian sampel apabila kita bermaksud untuk menggeneralisasikan penelitian sampel, dikarenakan jumlah populasi sedikit maka sampel pada penelitian ini mengemukakan keseluruhan populasi yang ada yaitu 35 orang menggunakan sampling jenuh. Menrutu (Sugiyono, 2017) sampling jenuh yaitu teknik penelitian sampel bila semua anggota populasi digunakan sebagai berikut. Teknik pengumpulan data yang digunakan adalah daftar pertanyaan kusioner yang diberikan kepada responden penelitian yaitu karyawan di PT Angkasa Pura II (Persero) Kantor Cabang Kualanamu bagian Human Resource General Affair. Teknik analisis data yang digunakan adalah analisis regresi linier berganda.

\section{HASIL DAN PEMBAHASAN}

\section{Hasil Penelitian}

\section{Uji Asumsi Klasik}

Hasil pengolahan data dengan SPSS tentang pengaruh variabel motivasi (X1), disiplin (X2), kepuasan kerja (X3), terhadap kinerja (Y), maka dapat dilihat dengan menggunakan asumsi klasik yaitu:

\section{Uji Normalitas}

Uji normalitas berutjuan untuk menguji apakah dalam model regresi, variabel dependen dan independen memiliki distribusi normal atau tidak. Jika datanya menyebar di sekitar garis diagonal dan mengikuti arah garis diagonal maka model regresi memenuhi asumsi normalitas.

Berdasarkan hasil pengolalahan data menggunakan SPSS versi 19.0 maka dapat diketahui uji normalitas menggunakan metode P-Plot sebagai berikut: 


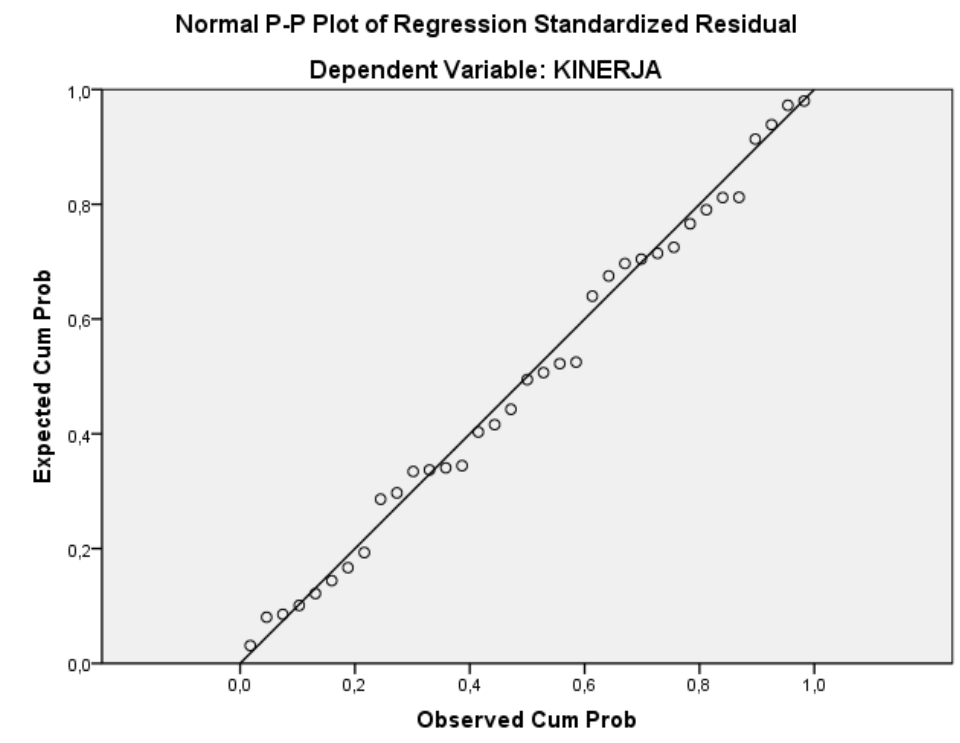

Sumber: Data Diolah 2019

Gambar 1. Uji Normalitas P-Plot

Gambar tersebut menunjukan bahwa titik-titik telah membentukan dan mengikuti arah garis diagonal pada gambar, dengan demikian dapat disimpulkan bahwa data telah terdistribusi secara normal.

\section{Uji Multikolenaritas}

Uji multikolinearitas bertujuan untuk menguji apakah model regresi di temukan adanya korelasi antar variabel bebas. Model regresi yang baik seharusnya tidak terjadi korelasi di antara variabel independen. Jika variabel independen saling berkorelasi, maka variabel-variabel ini tidak orthogonal. Variabel orthogonal adalah variabel independen sama dengan nol. Hasil uji multikolinieritas dapat dilihat pada tabel berikut ini :

Tabel 1. Hasil Uji Multikonearitas

\begin{tabular}{llrr}
\hline \multirow{2}{*}{ Model } & \multicolumn{2}{c}{ Collinearity Statistics } \\
\cline { 2 - 4 } (Constant) & & \\
\hline & Tolerance & VIF \\
\cline { 2 - 4 } & MOTIVASI &, 669 & 1,495 \\
\cline { 2 - 4 } & DISIPLIN &, 710 & 1,409 \\
\cline { 2 - 4 } KEPUASAN KERJA &, 789 & 1,267 \\
\hline
\end{tabular}

a. Dependent Variable: KINERJA

Jika dilihat pada tabel diatas diketahui bahwa hasil perhitungan tolarance menunjukan bahwa motivasi (X1) meniliki nilai 0,669, disiplin (X2) meniliki nilai 0,710 dan kepuasan kerja (X3) memiliki nilai 0,789 . Ketiga nilai ini lebih besar dari $>0,10$ yang artinya tidak ada korelasi antara variabel bebas. Kemudian, hasil perhitungan nilai varian inflation factor (VIF) menunjukan bahwa motivasi (X1) memiliki nilai 1,495 dan disiplin (X2) memiliki nilai 1,409 dan kepuasan kerja memiliki nilai 1,267. Ketiga nilai variabel tersebut $<10,00$. Jadi dapat disimpulkan bahwa tidak ada terjadi multikolinieritas antara variabel bebas dalam model regresi. 


\section{Uji Heteroskedastisitas}

Uji Heteroskedastisitas bertujuan untuk mengkuji apakah dalam model regresi terjadi ketidaknyamanan variance dari residual pengamatan satu ke pengamatan yang lain. Jika variance residual dari suatu pengamatan yang lain tetap maka dikatakan homokedastisitas, dan jika variance berbeda dikatakan heteroskedastisitas. Model yang baik adalah tidak terjadi heteroskedastisitas.

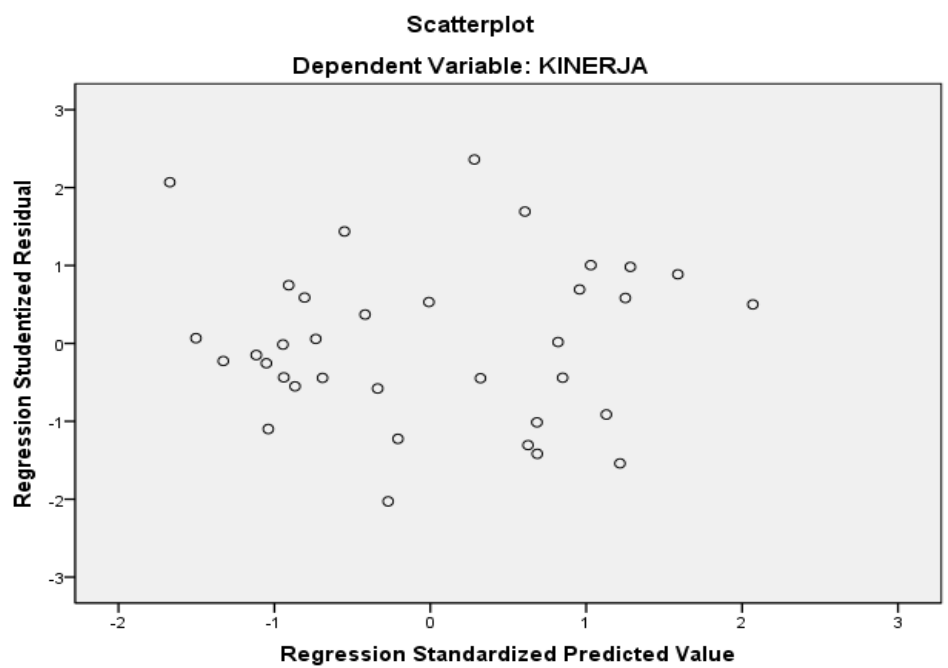

\section{Sumber: Data Diolah 2019}

\section{Gambar 2. Uji Heteroskedastisitas Menggunakan Scatterplot}

Uji ini akan menyatakan terbetas dari heteroskedastisitas jika titik-titik yang terdapat pada gambar tersebar secara acak. Gambar di atas menujukan suatu pola yang tidak jelas menyebar baik diatas mampun dijawab angka 0 pada sumbu $Y$.

\section{Regresi Linier Berganda}

Analisis regresi disusun untuk melihat hubungan yang terbangun antara variabel penelitian, apakah hubungan yang terbangun positif atau hubungan negatif. Berdasarkan olahan data yang dilakukan, amaka dapat diketahui bahwa model hubungan dari analisis regresi linier berganda dapat dilihat dari tabel dibawah ini :

Tabel 2. Hasil Regresi Linier Berganda Coefficients $^{\mathbf{a}}$

\begin{tabular}{|c|c|c|c|c|c|}
\hline \multirow[b]{2}{*}{ Model } & \multicolumn{5}{|c|}{ Unstandardized Coefficients Standardized Coefficients } \\
\hline & B & Std. Error & Beta & $\mathrm{T}$ & Sig. \\
\hline 1 (Constant) & 3,070 & 4,109 & & ,747 & 461 \\
\hline MOTIVASI & ,336 & ,095 & ,407 & 3,556 & 001 \\
\hline DISIPLIN & 178 & ,095 & ,210 & 1,888 &, 068 \\
\hline KEPUASAN KERJA & ,419 & ,098 & ,453 & 4,297 & ,000 \\
\hline
\end{tabular}

a. Dependent Variable: KINERJA

Berdasarkan pada tabel diatas maka dapat disusun model penelitian persamaan regresinya adalah sebagai berikut:

$$
\mathrm{Y}=3,70+0,336 \mathrm{X}_{1}+0,178 \mathrm{X}_{2}+0,419 \mathrm{X}_{3}
$$

Model persamaan regresi berganda tersebut bermakna:

a. Nilai konstanta sebesar 3,070 yang berarti bahwa jika variabel independen yaitu motivasi (X1), Disiplin (X2), dan Kepuasan Kerja (X3) = nol, maka kinerja (Y) adalah sebesar 3,070.

b. nilai koefisien regresi $\mathrm{X} 1=0,336$ menunjukan apabila motivasi mengalami kenaikan sebesar 100\%, maka akan meningkat kinerja karyawan PT Angkasa II (Persero) Kantor 
Cabang Kualanamu sebesar 33,6\%, kontribusi yang diberikan motivasi terhadap kinerja karyawan dilihat dari Unstandardized Coefficients pada tabel diatas.

c. Nilai koefisien regresi $\mathrm{X} 2=0,178$ menunjukan apabila disiplin mengalami kenaikan sebesar 100\% maka akan mengakibatkan eningkatnya kinerja karyawan PT. Angkasa Pura II (Persero) Kantor Cabang Kualanamu, sebesar 17,8 \% kontribusi yang diberikan disiplin terhadap kinerja karyawan dilihat dari Unstandardized Coefficients pada tabel diatas.

d. nilai koefisien regresi X3 =0,419 menunjukan apabila kepuasan kerja mengalami kenaikan sebesar 100\% maka akan mengakibatkan eningkatnya kinerja karyawan PT. Angkasa Pura II (Persero) Kantor Cabang Kualanamu, sebesar 41,9 \% kontribusi yang diberikan keouasan kerja terhadap kinerja karyawan dilihat dari Unstandardized Coefficients pada tabel diatas.

\section{Uji Hipotesis}

\section{Uji Parsial (Uji t)}

Uji statistik t dilakukan untuk menguji apakah variabel bebas (X) secara individual mempunyai pengaruh yang signifikan atau tidak terhadap variabel terikat (Y).

\section{Tabel 3. Uji t}

Coefficients $^{\mathrm{a}}$

\begin{tabular}{|c|c|c|c|c|c|}
\hline \multirow[b]{2}{*}{ Model } & \multicolumn{2}{|c|}{$\begin{array}{l}\text { Unstandardized } \\
\text { Coefficients }\end{array}$} & Standardized Coefficients & \multirow[b]{2}{*}{$\mathrm{T}$} & \multirow[b]{2}{*}{ Sig. } \\
\hline & B & Std. Error & Beta & & \\
\hline 1 (Constant) & 3,070 & 4,109 & & ,747 & ,461 \\
\hline MOTIVASI & ,336 & ,095 & 407 & 3,556 & 001 \\
\hline DISIPLIN &, 178 & ,095 & ,210 & 1,888 &, 068 \\
\hline KEPUASAN KERJA & ,419 & ,098 & ,453 & 4,297 & ,000 \\
\hline
\end{tabular}

a. Dependent Variable: KINERJA

Berdasarkan hasil $t_{\text {hitung }}$ perlu diketahui taraf signifikansinya berdasarkan $t_{\text {tabel }}$ dengan menggunakan rumus $n-k$ atau 35-3 = 32, dari hasil $t_{\text {tabel }}$ dapat diketahui nilai $t_{\text {tabel }} 1,693$.

\section{Pengaruh Motivasi terhadap Kinerja}

Pada tabel 3 dapat diketahui bahwa variabel $\mathrm{X}_{1}$ yaitu motivasi memiliki signifikan sebesar 0,01 lebih kecil dari $\alpha=0,05$ atau nilai $t_{\text {hitung }}$ sebesar 3,556 $>t_{\text {tabel }} 1,693$. Dapat disimpulkan bahwa motivasi $\left(\mathrm{X}_{1}\right)$ secara parsial mempunyai pengaruh positif dan signifikan terhadap kinerja (Y) pada PT Angkasa Pura II (Persero) Kantor Cabang Kualanamu.

\section{Pengaruh Disiplin terhadap Kinerja}

Pada tabel 3 dapat diketahui bahwa variabel $\mathrm{X}_{2}$ yaitu disiplin memiliki signifikan sebesar 0,68 lebih besar dari $\alpha=0,05$ atau nilai $t_{\text {hitung }}$ sebesar $1,888>t_{\text {tabel }} 1,693$. Dapat disimpulkan bahwa disiplin $\left(\mathrm{X}_{2}\right)$ secara parsial mempunyai pengaruh positif tetapi tidak signifikan terhadap kinerja (Y) pada PT Angkasa Pura II (Persero) Kantor Cabang Kualanamu.

\section{Pengaruh Kepuasan Kerja Terhadap Kinerja}

Pada tabel 3 dapat diketahui bahwa variabel $\mathrm{X}_{3}$ yaitu kepuasan kerja memiliki signifikan sebesar $0,00>\alpha=0,05$ atau nilai $t_{\text {hitung }}$ sebesar 4,297 $>t_{\text {tabel. }}$. Dapat disimpulkan bahwa kepuasan kerja $\left(\mathrm{X}_{3}\right)$ secara parsial mempunyai pengaruh positif dan signifikan terhadap kinerja (Y) pada PT Angkasa Pura II (Persero) Kantor Cabang Kualanamu.

\section{Uji Simultan (Uji F)}

Uji statistik F (simultan) dilakukan untuk mengetahui apakah variabel bebas (independent) secara bersama-sama berpengaruh secara signifikan atau tidak terhadap variabel terikat (dependen). Hasil uji secara simultan dapat dilihat dari tabel dibawah ini : 
Tabel 4. Uji F

\begin{tabular}{ccccccc}
\hline & Model & Sum of Squares & df & Mean Square & F & Sig. \\
\hline \multirow{3}{*}{1} & Regression & 523,548 & 3 & 174,516 & 27,724 &, $000^{\text {a }}$ \\
\cline { 2 - 7 } & Residual & 195,138 & 31 & 6,295 & & \\
\cline { 2 - 7 } & Total & 718,686 & 34 & & & \\
\hline
\end{tabular}

a. Predictors: (Constant), Kepuasan Kerja, Disiplin, Motivasi

b. Dependent Variable: Kinerja

Sumber:Data Diolah 2019

Berdasarkan dari tabel uji $\mathrm{F}$ diketahui bahwa terdapat nilai signifikan sebesar 0,000 nilai signifikan ini lebih kecil dari 0,05 artinya bahwa motivasi, disiplin dan kepuasan kerja berpengaruh signifikan terhadap kinerja karyawan pada PT. Angkasa Pura II (Persero) Kantor Cabang Kualanamu. Jika dibandingkan nilai $F_{\text {hitung }}$ dengan $F_{\text {tabe }} l$ maka dihasilkan 27,724 > 2.91 sehingga di simpulkan bahwa motivasi, disiplin dan kepuasan kerja berpengaruh signifikaan terhadap kinerja karyawan pada PT. Angkasa Pura II (Persero) Kantor Cabang Kualanamu.

\section{Koefisien Determinasi}

Uji determinasi ini untuk melihat seberapa besar motivasi, disiplin , dan kpeuasan kerja dalam menjelaskan variasi variabel dependen yaitu kinerja. Untuk mengetahui besarnya determinasi motivasi, disiplin, dan kpeuasan kerja dalam menjelaskan variasi variabel dependennya yaitu kinerja dapat dilihat pada tabel berikut ini

Tabel 5. Koefisien Determinasi

\begin{tabular}{lrrrr}
\hline Model & $\mathrm{R}$ & $\mathrm{R}$ Square & $\begin{array}{c}\text { Adjusted R } \\
\text { Square }\end{array}$ & $\begin{array}{c}\text { Std. Error of } \\
\text { the Estimate }\end{array}$ \\
\hline 1 &, $854^{\mathrm{a}}$ &, 728 &, 702 & 2,509 \\
\hline a. Predictors: (Constant), Kepuasan Kerja, Disiplin, Motivasi
\end{tabular}

\section{Sumber: Data Diolah 2019}

Berdasarkan pada tabel di atas diketahui bahwa nilai $\mathrm{R}_{\text {square }}$ adalah sebesar 0,728 atau sama dengan 72,8\% artinya bahwa motivasi, disiplin, dan kepuasan kerja mampu untuk menjelaskan kinerja karyawan di PT. Angkasa Pura II (Persero) Kantor Cabang Kualanamu adalah sebesar $72,8 \%$ dan sisanya $27,2 \%$ dijelaskan oleh variabel bebas yang lainnya yang tidak diikutsertakan ke dalam model penelitian ini.

\section{Pembahasan}

Dari hasil pengujian terlihat bahwa semua variabel bebas motivasi, disiplin dan kepuasan kerja mempunyai pengaruh terhadap variabel kinerja untuk lebih memperjelas terhadap rincian hasil analisis dan pengujian tersebut dapat di jelaskan sebagai berikut :

\section{Pengaruh Motivasi terhadap Kinerja}

Berdasarkan hasil penelitian mengenai pengaruh antara motivasi terhadap kinerja karyawan pada PT. Angkasa Pura II (Persero) Kantor Cabang Kualanamu yang menyatakan $t_{\text {hitung }} \geq t_{\text {tabel }}$ yaitu $3.556 \geq 1.695$ berada di daerah penerimaan Ha sehingga H0 ditolak, hal ini dinyatakan bahwa motivasi berpengaruh signifikan secara parsial terhadap kinerja karyawan di PT. Angkasa Pura II (Persero) Kantor Cabang Kualanamu. Dengan demikian, dapat disimpulkan bahwa variabel motivasi secara parsial berpengaruh positif dan signifikan yang artinya pengaruh kuat sekali terhadap kinerja karyawan. Sehingga motivasi sangatlah penting untuk menunjang kinerja karyawan, untuk itu dapat dipertahankan yang sudah baik namun perlu adanya dorongan motivasi bagi karyawan dengan memberikan pendidikan, pelatihan, atau workshop sehingga meningkatkan kinerja karyawan. 
Hasil penelitian ini menyatakan bahwa ada pengaruh positif dan signifikan antara motivasi terhadap kinerja. Hal ini diperkuat dengan hasil penelitian terdahulu (Gultom, 2014); (Prayogi \& Nursidin, 2018); (Andayani \& Tirtayasa, 2019); (Jufrizen, 2017); (Mujiatun, 2015); (Farisi, Irnawati, \& Fahmi, 2020); (Astuti \& Suhendri, 2019); (Rosmaini \& Tanjung, 2019); (Hasibuan \& Handayani, 2017); (Jufrizen \& Pulungan, 2017) yang menyimpulkan bahwa terdapat pengaruh positif motivasi terhadap kinerja karyawan.

\section{Pengaruh Disiplin Terhadap Kinerja}

Berdasarkan hasil penelitian mengenai pengaruh antara disiplin terhadap kinerja karyawan pada PT. Angkasa Pura II (Persero) Kantor Cabang Kualanamu yang menyatakan $t_{\text {hitung }} \leq t_{\text {tabel }}$ yaitu $1.888 \leq 1.695$ berada di daerah penerimaan Ha sehingga H0 ditolak, hal ini di nyatakan bahwa pelatihan berpengaruh tidak signifikan secara parsial terhadap kinerja karyawan di PT. Angkasa Pura II (Persero) Kantor Cabang Kualanamu. Denngan demikian dapat disimpulkan bahwa variabel disiplin secara parsial berpengaruh positif tetapi tidak signifikan terhadap kinerja karyawan. Sehingga disiplin sangatlah penting agar dapat memiliki tujuan dan kemampuan yang jelas dalam bekerja, pegawai juga memiliki rasa tanggung jawab yang besar terhadap pekerjaanya sehingga mampu meningkatkan kinerjanya.

Hasil penelitian ini menyatakan bahwa ada pengaruh positif tetapi tidak signifikan antara disiplin terhadap kinerja karyawan. Hal ini sejalan dengan penelitian terdahulu (Jufrizen, 2018); (Tanjung, 2016); (Arda, 2017); (Jufrizen, 2016); (Arif, Syaifani, Siswadi, \& Jufrizen, 2019); (Arif, Maulana, \& Lesmana, 2020); (Fahmi \& Sanika, 2017); (Yusnandar, Nefri, \& Siregar, 2020)(Prayogi \& Nursidin, 2019); (Hasibuan \& Silvya, 2019) yang menunjukkan bahwa disiplin berpengaruh positif dan signifikan terhadap kinerja karyawan.

\section{Pengaruh Kepuasan Kerja Terhadap Kinerja}

Berdasarkan hasil penelitian mengenai pengaruh kepuasan kerja terhadap kinerja pada PT. Angkasa Pura II (Persero) Kantor Cabang Kualanamu yang menyatakan $t_{\text {hitung }} \geq t_{\text {tabel }}$ yaitu 4,297 $\geq 1.695$ berada di daerah penerimaan Ha sehingga H0 ditolak, hal ini di nyatakan bahwa kepuasan kerja berpengaruh signifikan secara parsial terhadap kinerja karyawan di PT. Angkasa Pura II (Persero) Kantor Cabang Kualanamu. Dengan demikian dapat disimpulkan bahwa variabel kepuasan kerja secara parsial berpengaruh positif dan signifikan artinya pengaruh kuat sekali terhadap kinerja karyawan. Sehingga kepuasan kerja sangatla penting untuk dapat menunjang kinerja karyawan, untuk itu perlu dipertahankan yang sudah baik dan harus terus melakukan evaluasi dan peningkatan kepuasan kerja seperti gaji yang sesuai dengan tanggung jawab, lingkungan kerja yang baik dan penempatan kerja yang sesuai dengan keahlianya masing-masing agar mampu meningkatkan kinerja karyawan.

Hasil penelitian menyatakan bahwa ada pengaruh positif dan signifikan antara kepuasan kerja terhadap kinerja karyawan. Hal ini sejalan dengan hasil penelitian terdahulu (Adhan, Jufrizen, Prayogi, \& Siswadi, 2020); (Jufrizen, 2017); (Jufrizen, 2016); (Syahputra \& Jufrizen, 2019); (Jufrizen, Lumbanraja, Salim, \& Gultom, 2017); (Jufrizen, Gultom, Sitorus, Sari, M., \& Nasution, 2018) yang menunjukkan bahwa kepuasan kerja berpengaruh positif dan signifikan terhadap kinerja karyawan.

\section{Pengaruh Motivasi, Disiplin, dan Kepuasan Kerja Terhadap Kinerja}

Berdasarkan hasil penelitian mengenai pengaruh motivasi, disiplin, dan kepuasan kerja terhadap kinerja karyawan di PT. Angkasa Pura II (Persero) Kantor Cabang Kualanamu pada penelitian ini sudah jelas terbukti ada pengaruh secara simultan, di mana hasil uji $\mathrm{F}$ di dapat nilai $F_{\text {hitung }} \geq F_{\text {tabel }}$ yaitu $27,724 \geq 2.91$ dengan signifikan $0,000<0,05$. Karena $F_{\text {hitung }}$ lebih besar 
dari $\mathrm{F}_{\text {tabel }}$ maka $\mathrm{HO}$ di tolak dan $\mathrm{Ha}$ di terima artinya ada pengaruh antara motivasi, disiplin, dan kepuasan kerja terhadap kinerja karyawan di PT. Angkasa Pura II (Persero) Kantor Cabang Kualanamu.

Dapat disimpulkan secara simultan antara variabel motivasi, disiplin dan kepuasan kerja terhadap kinerja karyawan berpengaruh positif dan signifikan. Untuk itu perlu dipertahankan yang sudah baik dan harus terus dilakukan evaluasi dan peningkatan dalam pengetahuan jenis pekerjaan agar dapat mengahasilan kinerja yang maksimal.

\section{KESIMPULAN}

Berdasarkan hasil analisis yang telah dibahas pada bab terdahulu maka dapat kita simpulkan sebagai berikut: Hasil penelitian menujukan bahwa ada pengaruh positif dan signifikan antara variabel motivasi dengan variabel kinerja pada PT. Angkasa Pura II (Persero) Kantor Cabang Kualanamu, ada pengaruh positif tidak siginifikan antara variabel disiplin dengan variabel kinerja pada PT. Angkasa Pura II (Persero) Kantor Cabang Kualanamu, ada pengaruh positif dan signifikan antara variabel kepuasan kerja dengan variabel kinerja pada PT. Angkasa Pura II (Persero) Kantor Cabang Kualanamu dan motivasi, disiplin dan kepuasan kerja secara simultan berpengaruh positif dan signifikan terhadap kinerja karyawan di PT. Angkasa Pura II (Persero) Kantor Cabang Kualanamu. Beberapa saran yang diberikan antara lain motivasi sangatlah penting untuk dapat menunjang kinerja karyawan, untuk itu perlu dipertahankan yang sudah baik dan harus terus dilakukan evaluasi dan peningkatan motivasi seperti atasan memberikan bimbingan, keamanan di tempat kerja, pelatihan, peralatan ditempat kerja dan hak cuti kepada karyawan agar dapat meningkatkan kinerja karyawan. Disiplin sangatlah penting untuk dapat menunjang kinerja karyawan, untuk itu perlu dipertahankan yang sudah baik dan harus terus dilakukan evaluasi dan peningkatan disiplin seperti kemampuan yang jelas dalam bekerja, bersikap adil dalam menegakan disiplin, ketempat kerja lebih awal dan menyelesaikan pekerjaan yang menjadi tanggung jawab agar dapat meningkatkan kinerja karyawan yang lebih baik. Kepuasan kerja sangatlah penting untuk dapat menunjang kinerja karyawan, untuk itu perlu dipertahankan yang sudah baik dan harus dilakukan evaluasi dan peningkatan kepuasan kerja seperti gaji sesuai dengan tanggung jawab, lingkungan kerja yang mendukung, penempatan kerja sesuai dengan keahlian dan sifat pekerjaan ini sebagai tantangan agar dapat maningkatkan kinerja karyawan yang lebih baik. Hasil penelitian ini bisa dijadikan suatu refrensi bagi pihak-pihak yang ingin menjadikan tesis ini menjadi refrensi maka tesis ini diperbolehkan dan dapat bisa lebih menyempurnakanya lagi.

\section{DAFTAR PUSTAKA}

Adhan, M., Jufrizen, J., Prayogi, M. A., \& Siswadi, Y. (2020). Peran Mediasi Komitmen Organisasi pada Pengaruh Kepuasan Kerja terhadap Kinerja Dosen Tetap Universitas Swasta di Kota Medan. Jurnal Samudra Ekonomi Dan Bisnis, 11(1), 1-15. https://doi.org/10.33059/jseb.v11i1.1654

Afandi, P. (2016). Concept \& Indicator: Human Resources Management For Management Research. Yogyakarta: Deepublish.

Andayani, I., \& Tirtayasa, S. (2019). Pengaruh Kepemimpinan, Budaya Organisasi, Dan Motivasi Terhadap Kinerja Pegawai. Maneggio: Jurnal Ilmiah Magister Manajemen, 2(1), 45-54. https://doi.org/10.30596/maneggio.v2i1.3367

Arda, M. (2017). Pengaruh Kepuasan Kerja Dan Disiplin Kerja Terhadap Kinerja Karyawan Pada Bank Rakyat Indonesia Cabang Putri Hijau Medan. Jurnal Ilmiah Manajemen Dan Bisnis, 18(1), 45-60. https://doi.org/10.30596/jimb.v18i1.1097 
Arif, M., Maulana, T., \& Lesmana, M. T. (2020). Pengaruh Disiplin Kerja dan Kemampuan Kerja Terhadap Prestasi Kerja Karyawan. Jurnal Humaniora: Jurnal Ilmu Sosial, Ekonomi Dan Hukum, 4(1), 106-119. https://doi.org/10.30601/humaniora.v4i1.515

Arif, M., Syaifani, P. E., Siswadi, Y., \& Jufrizen, J. (2019). Effect of Compensation and Discipline on Employee Performance. In Proceeding of The 3rd International Conference on Accounting, Business \& Economics (UII-ICABE 2019) (pp. 263-276).

Astuti, R., \& Suhendri, S. (2019). Pengaruh Kompensasi Dan Motivasi Terhadap Kinerja Karyawan pada PT. Tunas Jaya Utama. Jurnal Manajemen Bisnis Eka Prasetya: Penelitian Ilmu Manajemen, 5(2), 1-10.

Bernardin, H. J., \& Russel, J. E. . (2010). Human Resource Management. New York: McGraw - Hill.

Edison, E., Anwar, Y., \& Komariah, I. (2016). Manajemen Sumber Daya Manusia. Bandung: Alfabeta.

Fahmi, I. (2017). Manajemen Sumber Daya Manusia Teori dan Aplikasi. Bandung: Alfabeta.

Fahmi, M., \& Sanika, F. (2017). The Influence of Leadership and Work Discipline Towards Employee Performance at PT. Kereta Api Indonesia (Persero) Divisi Regional I Sumatera Utara. Journal Of International Conference Proceedings (JICP), (3), 161-169.

Farisi, S., Irnawati, J., \& Fahmi, M. (2020). Pengaruh Motivasi dan Disiplin Kerja Terhadap Kinerja Karyawan. Jurnal Humaniora : Jurnal Ilmu Sosial, Ekonomi Dan Hukum, 4(1), 15-33. https://doi.org/10.30601/humaniora.v4i1.420

Gultom, D. K. (2014). Pengaruh Budaya Organisasi Perusahaan Dan Motivasi Terhadap Kinerja Karyawan pada PT. Perusahaan Gas Negara (Persero) Tbk Medan. Jurnal Ilmiah Manajemen Dan Bisnis, 14(2), 176-184. https://doi.org/10.30596/jimb.v14i2.194

Hamali, A. Y. (2016). Manajemen Sumber Daya Manusia (1st ed.). Yogyakarta: Media Pressindo Group.

Hasibuan, J. S., \& Handayani, R. (2017). Pengaruh Disiplin dan Motivasi Terhadap Kinerja Karyawan Pada PT. Kemasindo Cepat Nusantara Medan. Kumpulan Jurnal Dosen Universitas Muhammadiyah Sumatera Utara, 418-428.

Hasibuan, J. S., \& Silvya, B. (2019). Pengaruh Disiplin Kerja dan Motivasi Terhadap Kinerja Karyawan. In Prosiding Seminar Nasional Multidisiplin Ilmu (pp. 134-147).

Hasibuan, Malayu S. P. (2011). Manajemen Sumber Daya Manusia. Edisi Revisi Jakarta: Bumi Aksara. Jakarta: Bumi Aksara.

Hasibuan, Malayu S.P. (2013). Manajemen Sumber Daya Manusia. Jakarta: Bumi Aksara.

Hasibuan, Malayu S.P. (2014). Manajemen Sumber Daya Manusia. Jakarta: Bumi Aksara.

Hasibuan, Melayu S.P. (2016). Manajemen Sumber Daya Manusia (Revisi). Jakarta: Bumi Aksara.

Jufrizen, J. (2018). Peran Motivasi Kerja Dalam Memoderasi Pengaruh Kompensasi Dan Disiplin Kerja Terhadap Kinerja Karyawan. Prosiding: The National Conferences Management and Business (NCMAB) 2018, 405-424.

Jufrizen, J., Gultom, D. K., Sitorus, S. A., Sari, M., \&, \& Nasution, M. I. (2018). The Effect Of Organizational Culture And Islamic Work Ethic On Permanent Lectures' Job Satisfaction, Organizational Commitment And Work Performance At Private Islamic Universities In the City Medan. In Proceeding 1st International Conference of Economic Studies (ICOES), 179-186.

Jufrizen, J. (2016). Efek Mediasi Kepuasan Kerja Pada Pengaruh Kompensasi Terhadap Kinerja Karyawan. Jurnal Ilmiah Manajemen Dan Bisnis, 17(1). https://doi.org/10.30596/jimb.v17i1.1209

Jufrizen, J. (2016). Pengaruh Pengawasan Terhadap Kinerja Karyawan Melalui Disiplin Kerja 
Pada PT. Socfin Indonesia Medan. Jurnal Ilmiah Manajemen Dan Bisnis, 17(2), 181-195. Jufrizen, J. (2017). Pengaruh kemampuan dan motivasi terhadap kinerja perawat Studi pada Rumah Sakit Umum Madani Medan. Jurnal Riset Sains Manajemen, 1(1), 27-34. https://doi.org/10.5281/zenodo.1036809

Jufrizen, J. (2017). Pengaruh Kepemimpinan dan Budaya Organisasi Terhadap Kinerja dengan Kepuasan Kerja sebagai Variabel Intervening. Jurnal Ilmiah Kohesi, 1(1), 166-177.

Jufrizen, J., Lumbanraja, P., Salim, S. R. A., \& Gultom, P. (2017). The Effect of Compensation, Organizational Culture and Islamic Work Ethic Towards the Job Satisfaction and the Impact on the Permanent Lecturers. International Business Management, 11(1), 53-60.

Jufrizen, J., \& Pulungan, D. R. (2017). Implementation of Incentive and Career Development of Performance with Motivation as an Intervening Variable. In Proceedings of AICS-Social Sciences (pp. 441-446).

Juliandi, A., Irfan, I., \& Manurung, S. (2015). Metode Penelitian Bisnis : Konsep \& Aplikasi. Medan: UMSU Press.

Mangkunegara, A. A. A. P. (2018). Manajemen Sumber Daya Manusia Perusahaan. Bandung: PT. Remaja Rosdakarya Offset.

Mathis, R. L., \& Jackson, J. H. (2011). Human Resource Management (Manajemen Sumber Daya Manusia). Jakarta: Salemba Empat.

Moeheriono, M. (2014). Pengukuran Kinerja Berbasis Kompetensi (Revisi). Jakarta: PT Raja Grafindo Persada.

Mujiatun, S. (2015). Pengaruh Kepuasan Kerja dan Motivasi Kerja Terhadap Kinerja Pada PT Rajawali Nusindo Medan. Jurnal Ilmiah Manajemen Dan Bisnis, 16(2).

Prayogi, M. A., \& Nursidin, M. (2018). Pengaruh Pelatihan dan Motivasi Kerja Terhadap Kinerja Karyawan. In Prosiding Seminar Nasional Multidisiplin Ilmu Universitas Asahan 2018 (pp. 216-222).

Prayogi, M. A., \& Nursidin, M. (2019). Pengaruh kompetensi dan Disiplin Kerja Terhadap Kinerja Karyawan. Festifal Riset Ilmiah Manajemen Dan Akuntansi, 1(11), 1-5.

Rivai, V., \& Sagala, E. . (2013). Manajemen Sumber Daya Manusia Untuk Perusahaan. Jakarta: Jakarta: Rajawali Pers.

Rosmaini, R., \& Tanjung, H. (2019). Pengaruh Kompetensi, Motivasi Dan Kepuasan Kerja Terhadap Kinerja Pegawai. Maneggio: Jurnal Ilmiah Magister Manajemen, 2(1), 1-15. https://doi.org/10.30596/maneggio.v2i1.3366

Simajuntak, P. J. (2011). Manajemen dan Evaluasi Kinerja. Jakarta: Lembaga Penerbit Fakultas Ekonomi Universitas Indonesia.

Sugiyono, S. (2017). Metode Penelitian Kuantitatif, Kualitatif, Kombinasi (Mixed Methods). Bandung: ALFABETA,Cv.

Sunyoto, D. (2012). Manajemen Sumber Daya Manusia. Jakarta: PT Buku Seru.

Sutrisno, E. (2016). Manajemen Sumber Daya Manusia. Jakarta: Kencana Prenada Media Group.

Syahputra, I., \& Jufrizen, J. (2019). Pengaruh Diklat, Promosi, Dan Kepuasan Kerja Terhadap Kinerja Pegawai. Maneggio: Jurnal Ilmiah Magister Manajemen, 2(1), 104-116. https://doi.org/10.30596/maneggio.v2i1.3364

Tanjung, H. (2016). Pengaruh Disiplin Kerja, Kompetensi Dan Budaya Organisasi Terhadap Kepuasan Kerja Pegawai Pada Dinas Perkebunan Sumatera Utara. Jurnal Konsep Bisnis Dan Manajemen, 3(1), 111-122.

Umar, H. (2011). Riset Sumber Daya Manusia Dalam Organisasi. Jakarta: PT. Gramedia Pustaka Utama.

Walgito, B. (2007). Piskologi Sosial: Suatu Pengantar. Yogyakarta: Andi Offset. 
Wibowo, W. (2014). Perilaku Dalam Organisasi. Jakarta: Rajawali Pres.

Wibowo, W. (2014). Manajemen Kinerja (Edisi Keenam). Jakarta: Jakarta: Rajawali Pers.

Widodo, W. (2015). Manajemen Pengembangan Sumber Daya Manusia. Yogyakarta: Pustaka Pelajar.

Winardi, W. (2012). Manajemen Sumber Daya Manusia. Jakarta: Prenada Media Group.

Yusnandar, W., Nefri, R., \& Siregar, S. (2020). Pengaruh Disiplin Kerja Dan Pelatihan Terhadap Kinerja Karyawan Dengan Budaya Organisasi Sebagai Variabel Moderasi Pada Rumah Sakit Milik Pemerintah di Kota Medan. Jurnal Humaniora : Jurnal Ilmu Sosial, Ekonomi Dan Hukum, 4(1), 61-72. https://doi.org/10.30601/humaniora.v4i1.433 